\title{
The Effect of Employee Competence on the Reliability of Financial Statements
}

\author{
R. Ait Novatiani, R. Roosaleh Laksono \\ Faculty of Economy \\ Widyatama University \\ Bandung - Indonesia \\ ait.novatiani@widyatama.ac.id
}

\begin{abstract}
- often we find that the financial statement presented by a company occurred inaccuracy of time in preparing financial statements, causing delays in decision making. Financial statements is financial information used by the company as a means of decision making, the financial statements should be reliable and trustworthy. The financial statements should be made by employees who are competent in their field. The purpose of this research is to determine employee competence, reliability of the financial statements and the effect of employee's competence to the reliability of financial statements. The method used in this research is explanatory method, and sampling techniques using Non Probability Sampling with saturated sampling number 30 people in service of BUMN companies in Bandung. The statistical analysis used is the correlation analysis rank spearman, coefficient of determination, and $t$ test. The result showed that employee competency is adequate, the reliability of financial statement is adequate and the employee's competence significant effect to the reliability of financial statements
\end{abstract}

Keywords- Employee competence; reliability; financial statements

\section{INTRODUCTION}

The financial statements are the source of financial information used by the parties concerned to the financial statements as a tool for making decisions. The parties concerned to the financial statements the stakeholder are internal and external parties. Besides that the financial statements also as instrumental for company's managements responsibility for running the company and management company [1]. Therefore, the financial statements should be really a concern.

The financial statements should be presented at the pair, shows presented with honest, trustworthy, useful and reliable. Needs four main quality to keep the financial statements presented with honest, trustworthy, useful and reliable, that are understandable, relevant, reliability and comparable. The financial statement commonly used by companies are consists of statement of financial position (balance sheet at was), income statement, cash flow statement, change of equity statement and financial statement notes. The financial statements as a useful information if the information it contains provided timely for decision makers before its loses in capacity to make effect in decision making [2].
In many cases, the financial statement manipulation make destruction of corporation. One of them can be found on website of liputan 6 , dated $5^{\text {th }}$ and $8^{\text {th }}$ August 2006 in the case of PT. KAI tbk. PT. KAI tbk explained that company had ignored good corporate governance. There has been a manipulation of data in their financial statements in year 2005. The company declared make profit $\mathrm{Rp} 60.9$ billion. Actually happened the company loss amount of Rp 63 billion. This loss occurs because the company can not collect the third party tax. But in their financial statements wrote, the third party uncollectable tax as income or asset. Based on accounting standard, that case can not grouped in income or assets. The mistake of transaction recording has occur in year 2005. Impairment of parts and supplies amount Rp 24 billion has known in year 2002, recognized by management as gradual loss for five years. In the end of year 2005 rest of balance of Rp 6 billion, Its should be fully spent entirely in 2005 [3] and [4]. From on explanation above, the financial statement of PT. $\mathrm{KAI}$ is not reliable.

One of the factors that may affect the reliability of a financial statement is competent employee in their field. That competencies include the knowledge, skill and attitude [5]. Therefore, research on the effect of employee competencies to the reliability of financial statements to be important to do.

This research is in line with research that has been done before. The application of good corporate governance to the reliability of financial statements in 3 (three) Bandung BUMN Companies in services have effect to the financial statement reliability [6]. The effect of employee competence on the quality of the presentation of the financial statements at 17 offices in SKPD in Bandung are significant effect to the quality of financial statements [7]. The differences between the research that I have done with previous research are variables to be studied, venue of the research (BUMN), and the respondence.

\section{METHOD}

Research method used was explanatory method, the research which explain variables and relation with other variables. 


\section{A. Variables}

Variables used in this research are independent variable and dependent variable. Independent variable is employee competent $(\mathrm{X})$, whereas dependent variable is the financial statement reliability (Y).

\section{B. Population and Samples}

Population in this research is the part of accounting section on BUMN in services company in Bandung, are PT. PLN (17 people) and PT. POS Indonesia (13 people). Sampling techniques used is non probability sampling with saturated sampling for 30 people. Data collecting techniques used are primary data by questioner and secondary data by library research.

\section{Data Analysis}

1) Data quality test

\section{Validity Test}

Validity test product moments with correlation coefficient [8], if the value more than $\geq 0,300$ is valid.

\section{Reability Test}

Reliability test applied with cronbach alpha coefficient [8], if the value of cronbach alpha $\geq 0,700$ is reliable.

2) Correlation Analysis, Determination Coefficient, and $t$-Test

Correlation analysis used Rank Spearman's formula. Rank Spearman formulated as below:

$$
r_{s}=1-\frac{6 \sum_{i=1}^{n} d_{i}^{2}}{n\left(n^{2}-1\right)}
$$

Explanation:

rs = Correlation coefficient Rank Spearman

$\mathrm{di}=$ Data different ranking variable $\mathrm{X}$ and $\mathrm{Y}$

$\mathrm{n}=$ sampling numbers

The power of strength in influence to reliable of financial statement described in Table I [9]. Coefficient of Rank Spearman (rs) will have a value $-1<\mathrm{rs}<1$, with condition below:

\section{TABLE I. INTERPRETATION OF COEFFICIENT CORRELATION GUIDE}

\begin{tabular}{|c|c|}
\hline Coefficient interval & Relation level \\
\hline $0,00-0,199$ & Very low \\
\hline $0,20-0,399$ & Low \\
\hline $0,40-0,599$ & Moderate \\
\hline $0,60-0,799$ & Strong \\
\hline $0,80-1,000$ & Very strong \\
\hline
\end{tabular}

Source: Sugiyono (2004), Business Research Method
Determination coefficient's formula:

$$
\mathrm{Kd}=\mathrm{r}^{2} \times 100 \%
$$

Making decision criteria, whether $\mathrm{H}_{0}$ accepted and $\mathrm{H}_{\mathrm{a}}$ rejected or $\mathrm{H}_{0}$ rejected and $\mathrm{H}_{\mathrm{a}}$ accepted with calculation of t-test. Formula of t-test is:

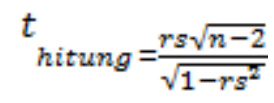

Explanation:

$\mathrm{n}=$ Sampling numbers

rs = Rank Spearman correlation coefficient value

If $t_{a} \geq t$ table, then $H_{0}$ rejected and $\mathrm{H}_{\mathrm{a}}$ accepted.

If $\mathrm{t}_{\mathrm{a}}<\mathrm{t}_{\text {table, }}$, then $\mathrm{H}_{0}$ rejected and $\mathrm{H}_{\mathrm{a}}$ rejected.

$\mathrm{H}_{0}$ : The employee competence no significant effect on the financial statements reliability.

$\mathrm{H}_{\mathrm{a}}$ : The employee competence have significant effect on the financial statements reliability.

The significant level used in this research is 0,05 .

\section{RESULT AND DISCUSSION}

Validity Test

The result of validity test using software SPSS 19 (statistical product and service solutions). The result of validity test of all items $\mathrm{X}$ variables and $\mathrm{Y}$ variables showed valid, because they have value $\geq 0,300$ for all items, $X$ and $Y$ variables.

\section{Reability Test}

The result of reliability has represented by software SPSS 19 (statistical product and service solutions). The result showed that validity test in all items $\mathrm{X}$ variables and $\mathrm{Y}$ variables were reliable, because they have value $\geq 0.700$

\section{Employee competence on services BUMN company in Bandung}

The result of research showed that employee competence on services of BUMN company in Bandung, PT. PLN and PT. POS Indonesia, are suffice, because supported by knowledge in accounting, skills in accounting and good attitudes. The research result in line with the theory that employee competence involve are knowledge, skill and attitude [5]. Besides that, data obtained from questioner to numbers of 30 respondents showed good, obtained 3.47 from average value from all of question. Point of 3.47 in position between 3.4 and 4.19 in good category. 
The realibility of Financial statement on service BUMN company in Bandung

The result of study showed that reliability of financial statement on service company of BUMN (PT. PLN and PT. POS Indonesia) are suffice, because they supported by financial statement qualitative characteristic as understandable, relevan, reliability and comparable. The research result in line with theory that financial report qualitative characteristic are: understandable, relevan, reliability and comparable [10]. It shows the reliable financial report is the financial report has fulfilled financial report qualitative characteristic. Beside that the result of data collection questioner distribution from 30 respondents, the reliabilities of financial report shows good., because obtained average value of 3.54. The point of 3.54 in interval between 3.40 to 4.19 in good category.

TABLE II.

RESPONDENTS RESPONSE CATEGORY

\begin{tabular}{|c|c|}
\hline Interval & Category \\
\hline $1.00-1.79$ & Very poor \\
\hline $1.80-2.59$ & Poor \\
\hline $2.60-3.39$ & Quite good \\
\hline $3.40-4.19$ & Good \\
\hline $4.20-5.00$ & Very good \\
\hline
\end{tabular}

The Effect of employee competence to reliability of financial statement on service BUMN company in Bandung.

In this research to know of employee competence effect to the reliable financial statement, the author needs testing in relationship level between $\mathrm{X}$ and $\mathrm{Y}$ variables as below:

\section{Correlation Analysis}

Determine of relations level between employee competence with reliability of financial statement used correlation rank spearman analysis. Points in Rank Spearman correlation obtained 0.659 , this points position between 0.60 to 0.799 , its mean have strong relations. The analysis show presence strong relationship between employee competence with reliable financial statement.

\section{Determination Coefficient}

Based on coefficient determination calculation obtained value of $49.85 \%$, that show to us that the reliable of financial statement effected by employee competence with $49.85 \%$.

\section{3. $t$-Test}

Based on calculation obtained $t_{\text {account }}$ of $4.510, t_{a}$ of 4.510 bigger than $t_{\text {table }}$ of 1.703 or $t_{a}>t_{\text {tabel. }}$. That shows to us that $\mathrm{H}_{\mathrm{a}}$ is accepted and $\mathrm{H}_{0}$ is rejected means the employee competence have significant effect to the reliable financial statement.
The result in line with other research result before by about the effect employee competence to financial report presentation quality on 17 offices in SKPD Kota Bandung [7]. The result showed that employee competence have significant effect to financial report presentation quality variables and the research about the effect application of good corporate governance to financial report reliabilities in 3 (three) company of BUMN in services, Bandung. It showed that the application of good corporate governance have effect for financial report reliabilities [6].

\section{CONCLUSION}

Based on result, the author have conclusion as below:

1. The employee competence on the BUMN company in the service in Bandung there are PT. PLN and PT. POS Indonesia already sufficient.

2. The reliable of financial statement on the BUMN company in the service in Bandung there are PT. PLN and PT. POS Indonesia already sufficient.

3. The employee competence have significant effect to the reliable of financial statement.

\section{REFERENCES}

[1] Ikatan Akuntan Indonesia, Pernyataan Standar Akuntansi Keuangan (Revisi 2009), Publisher: Salemba Empat, Jakarta 2009.

[2] Hanafi M. and A. Halim, Analisis Laporan Keuangan, Second Edition, Yogyakarta: YKPN, 2005.

[3] Liputan 6, Manipulasi Laporan Keuangan PT KAI 2006. http://www.news.liputan6.com accessed on February, $16^{\text {th }} 2014$.

[4] Andily A., Pengaruh Penerapan Good Corporate Governance Terhadap Kualitas Laporan Keuangan, Thesis, Widyatama University, 2014.

[5] Hutapea P. dan N. Thoha, Kompetensi Plus, Jakarta: PT Gramedia Pustaka Utama, 2008.

[6] Fatimmah J., Pengaruh Penerapan Good Corporate Governance Terhadap keandalan laporan keuangan pada 3 (tiga) perusahaan BUMN di bidang jasa - Bandung, Thesis, Widyatama University, 2012.

[7] Ningsih L., Pengaruh Kompetensi Pegawai Terhadap Kualitas Penyajian Laporan Keuangan, Thesis, Widyatama University, 2015.

[8] Sekaran U., Research Methods For Business (Metodologi Penelitian Untuk Bisnis), Jakarta: Salemba Empat, 2007.

[9] Sugiyono. 2004, Metode Penelitian Bisnis, Edisi Revisi, Bandung:Alfabet

[10] Ikatan Akuntan Indonesia, Standar Akuntansi Keuangan 2007, Publisher: Salemba Empat, Jakarta, 2007. 